\title{
Die korrektiewe aard van die Ou Testament en die betekenis daarvan vir teologiebeoefening
}

\author{
J.L. Helberg \\ Departement Ou \& Nuwe Testament \\ Potchefstroomse Universiteit vir $\mathrm{CHO}$ \\ POTCHEFSTROOM
}

\begin{abstract}
The corrective character of the Old Testament and its meaning in the practice of theology

This article briefly explores the character and content of the corrective element in the Old Testament and also draws the line through to the New Testament, i.e. to Jesus Christ. Attention is given to the attitude of the Old Testament to evil powers, man, the covenant people, the proclaimers of the Word, the listeners or readers, and the Old Testament itself. The relevance of this corrective element in the practice of theology is also cursorily explored. The conclusion is that theologv implies imperfect human reflection on Scripture as the perfect Word of God. Theology should be practised in humility, continually heing tested against Scripture as norm and accordingly being reformed. Furthermore, theology should not merely criticise or condemn other approaches but should have a missionary inclination.
\end{abstract}

\section{Inleiding}

Die Ou Testament staan nie neutraal teenoor die mens se lewe nie maar wel krities. Op grond van die sonde bevat die wet, profete en geskrifte al drie 'n aanklag teen die mens in die algemeen en teen Israel in besonder. Tog volstaan die Ou Testament nie met 'n veroordeling nie, maar is dit korrektief of korrigerend van aard en word die herstel van die verhouding tot God beoog, en gepaardgaande daarmee ook die heil vir die mens. (Die aard en intensiteit van die korreksie sal uit die bespreking duidelik word.) Die Ou Testament begin met aanklag en korreksie (Gen. 2-3) en eindig daarmee (Mal. 4); ook die slothoofstuk van die Geskrifte (2 Kronieke 36: 15-23) eindig daarmee. Hierdie artikel wil kortliks die aard en omvang van hierdie korrektiewe element in die Ou Testament nagaan en die lyn in 
die Nuwe Testament, dit wil sê in Christus, naspoor. In die lig van hierdie kritiese instelling teenoor die mens is die vraag verder: hoe krities is die Ou Testament dan oor die mens se aanbidding en oor die Woord wat deur middel van die mens ontvang is en/of tot stand gekom het? Anders gestel: laat God sy openbaring oor aan so 'n mens? Bied die Ou Testament homself aan as korrektiewe openbaring of as menslike weergawe, en daarom skeefgetrokke, en in dié sin gekorrigeerde openbaring? Aan die einde sal die bevinding se betekenis vir enkele aspekte van teologiebeoefening kortliks aangedui word.

\section{Die houding van die Ou Testament teenoor bose magte}

Die Ou Testament sluit soms by mitologiese uitdrukkings en voorstellings van die buurnasies aan, maar op apologetiese manier - as 'n korreksie daarop (vgl. Van Selms, 1967:44; Helberg, 1983:51). Israel se bure het 'n natuurgodsdiens beoefen. Hulle was onbewus van 'n soewereine en absolute Goddelike wil wat alles regeer en die oorsaak van alles is. Hulle het geglo aan hoofde van panteons, skeppers en onderhouers van die kosmos, maar wesens wat getransendeer is deur die oerwerklikheid met sy voorafbestaande, outonome magte. Uit hierdie radikale tweespaltigheid van die heidendom ontspring mitologie en magie (Kaufmann, 1961:22). Die Ou Testament daarenteen, praat ook van 'n stryd tussen God en die gode van die nasies, maar deel nie die mitologiese beskouings nie (Kaufmann, 1961: 11; Eichrodt, 1967:114). God is soewerein oor alles. Daar is geen magsfeer bo of naas Hom wat sy absolute mag beperk nie (Kaufmann, 1961: 60 ). Anders as by die buurnasies word die klem in verband met lyding in die wêreld in die Ou Testament nie gelê op die bose magte nie, maar op die mens en sy verantwoordelikheid (vgl. byvoorbeeld die plek van die slang in verband met die sonde; Gen. 2-3; Helberg, 1980: 24). Dieselfde gebeur in die boek Daniël wat handel oor die verbondsvolk se uitsiglose situasie waarin hulle lot bepaal word deur 'n voortdurende opvolging van wêreldryke. Hierdie ryke word as diere voorgestel en word self deur agterliggende bose magte bepaal. God is egter in volle beheer en uiteindelik tree Hy totaal korrigerend teen die bose magte op en vernietig hulle. Tog lê die boek die klem op menslike verantwoordelikheid en bekering (bv. by Nebukadnesar en by die gebed van Daniël; Dan. 4, 9; vgl. Helberg, 1994:106107, 132-134). Die Ou Testament is vry van mitologie en magie (Kaufmann, 1961:11,22; Eichrodt, 1961:41-44; 1967:270). 


\section{Die houding van die Ou Testament teenoor die mens}

Die mens word in die Ou Testament geteken as 'n sondige wese in vyandskap met God en die naaste; daarom is die houding teenoor die mens skerp en radikaal, hoewel nie bloot veroordelend nie. Geen handeling van God met die mensdom en/of Israel as geheel staan op homself en het die laaste woord nie, maar is ingebed binne die konteks van God se korrigerende, reddende wil. Die Woord is nie net veroordelend teenoor die mens nie, maar is gerig op die behoefte van die mens, soos gesien by die sondeval, die geskiedenis van Kain en die sondvloed (Gen. 2-3; 4; 6:5-6). Ná die sondvloed is die mense nog net so korrup as voorheen. Die Here volg nou egter 'n ander weg en lê 'n orde in die skepping vas wat 'n ordelike gang van die mens se lewe moontlik maak (Gen. 8:21-9:17).

Wanneer die mensdom ook hierna hulle rug op die Here draai, straf Hy hulle deur taalverwarring en verstrooiing (Gen. 11) maar korrigeer Hy ook hulle daad deur 'n ander eenheidsfaktor daar te stel, nie 'n ander stad nie, maar 'n persoon. Deur Abraham sal al die nasies die seën van die Here ontvang, afhangende van hulle houding teenoor Abraham en sy God (Gen. 12:1-3). Die roeping van Abraham vir hierdie taak hang saam met verkiesing en verbond, wat in wese 'n korrektiewe handeling van God is. God straf naamlik die sondige mensdom maar breek tog nie heeltemal die band met hom nie. Die Goddelike genadeweg met die mensdom gaan nou voort deur middel van hierdie uitverkore verbondsvolk deur wie daar uiteindelik redding vir die hele mensdom in vooruitsig gestel word. Israel moet anders wees as die nasies deur 'n gekorrigeerde opvatting oor God, die kultus, koningskap en regering en die sosio-ekonomiese lewe; kortom, oor die lewe in sy geheel.

Die lofsang van Hanna (1 Sam. 2:1-10) is 'n duidelike kommentaar van God se oordelende en korrektiewe optrede teenoor die skeefgetrokke, sondige wêreld waarin daar steeds behoefte is aan die omkering van die bestaande situasies van ryk en arm, hoog en laag, ensovoorts (Brueggemann, 1990:17-20).

In die Psalms word dikwels geworstel met die vraag oor die regverdigheid van God en met die probleem waarom God nie oordelend of korrigerend teenoor onreg optree nie (Ps. 7, 42-43, 73, ens.). Daar word voortdurend verwys na vyande van die psalmdigter en hulle word tegelykertyd beskou as vyande van God. Die digter is dikwels ongelukkig met hulle onreg en 
die voorspoed wat hulle geniet. Soms wens hy hulle die oordeel van God toe.

Ook by die profete speel vyandskap ' $n$ belangrike rol. Al drie die sogenaamde Groot Profete bevat oordeelsuitsprake oor die vyandige nasies (Jes. 13-23; Jer. 46-51; Eseg. 25-32). Ook in hulle eie verbondskring ondervind die profete vyandskap en selfs vervolging. Die profetiese verkondiging roep óf vyandskap óf korreksie op, dit wil sê bekering (die vals profete praat die mense egter na die mond; Jer. 28). Daniël 7-12 teken die wêreldryke as diere wat verskeur maar self vernietiging tegemoet gaan. Dit geld veral die onbekeerlike Antiogus Epifanes (ook die onbekeerlike Belsasar; Dan. 5, 7-11). Teenoor ander heersers, soos Nebukadnesar, openbaar die boek Daniël egter 'n simpatieke trek en roep hulle op tot bekering (Dan. 4:24-27).

Die Ou Testament getuig ook van 'n botsing tussen die Woord en die mens in sy reaksie op en verklaring van die Woord (vgl. die woorde van verleiding: "Is dit so dat God gesê het?" en die reaksie van Kain op God se woorde; Gen. 3:1; 4:14-15). Die Woord word beskou as effektief, soos blyk uit die refrein "en God het gesê" by die skepping (vgl. ook Jer. 23:29; Ps. 33:6, 9). By die roeping van Abraham is daar net van die Woord sprake en is daar eintlik 'n creatio ex nihilo (Gen. 12:1-3; Van Selms, 1967: 177). Hierdie effektiwiteit werk nie outomaties op die mens in nie, maar werk positief of negatief (Jes. 40:6-8) na gelang van die reaksie van die mens, en is daarom ten nouste verbind met 'n oproep tot bekering (Jes. 55: 6-11). Die doel van die Woord is om die mens te leer om werklik te luister sodat hy uit sy doofheid en blindheid kan kom en die Here werklik kan dien en gered word (Jes. 42:18-20; 50:4-10). Hierin speel die Heilige Gees 'n belangrike rol (Jes. 48:16; 61:1-2).

\section{Die houding van die Ou Testament teenoor die ver- bondsvolk}

Die Ou Testament benader Israel nie op 'n afsonderlike wyse nie, maar as deel van die mensdom en in wese niks beter as die ander nasies nie. Hoewel Israel die uitverkore verbondsvolk is, moet Israel bewus wees van hulle eie onwaardigheid, van die behoefte aan voortdurende bekering en van die verantwoordelikheid om volgens die wil van God te lewe. Die hele mensdom se belang is hierby ingesluit. Die Ou Testament gaan met Israel se geskiedenis terug tot voor die bestaan van Israel (Gen. 1; vgl. Gen. 11 anders as die buurnasies se geskiedbeskrywing wat hulle eie nasie se be- 
staan terugvoer tot by die skepping). Israel word dus geteken as deel van die sondige mensdom. Verder bly die universele perspektief van die $\mathrm{Ou}$ Testament nog bestaan en word die heil vir die nasies in vooruitsig gestel selfs wanneer Israel sedert die roeping van Abraham die besondere verbondsvolk van die Here is (Gen. 12:1-3; vgl. ook Jes. 2:2-4; 42:6; 49:6; ens.).

Die hele geskiedenis van Israel sedert die roeping van Abraham word gekenmerk deur sondige optrede enersyds, en God se genade en korrektiewe optrede teenoor Israel, andersyds (vgl. ook Isak en Jakob, Gen. 12: $10-20 ; 25: 22-28 ; 27)$. Ook die groot leier Moses, met wie die uittog uit Egipte en die Tien Gebooie geassosieer word, word as sondige mens geskets (Num. 20:8-13). Alleen God se korrektiewe optrede het dinge vir Israel uiteindelik goed laat verloop. Ook die groot Dawid word as sondige mens geteken (2 Sam. 1 1-12,24). Alleen deur God se genadige en korrektiewe optrede is die Messiaanse verwagtings van verlossing vir Israel blywend aan Dawid se nageslag verbind (2 Sam. 7).

Israel se woestynreis tipeer hulle voortdurend as 'n hardkoppige volk (Eks. $32: 9$; 34:9; Deut. 9:13). Verder is die Tien Gebooie grotendeels in 'n negatiewe en dus 'n korrektiewe vorm gegee: "Jy mag nie ..." (Eks. 20). Selfs terwyl Moses die Tien Gebooie vir Israel op skrif stel, word Israel afvallig van die Here en pleeg afgodery (Eks. 32). In die rigtertyd het Israel geen koning nie en elkeen doen wat goed is in sy eie oë. Wanneer daar wel 'n koning kom, is hy juis die oorsaak van Israel se ellende. Telkens word van 'n koning gesê dat hy gedoen het wat verkeerd is in die oë van die Here ( 2 Kon. $8: 27$; 13:11; 14:24; ens.). Die volk het saam met die koning gesondig en is saam in die afgrond ingetrek. Israel het behoefte gehad aan 'n korrektief op die koning; daarom het die verwagting van 'n Messiaanse koning gegroei (Bright, 1953:86-92; Preuss, 1992:36).

Die Psalms is vol getuienis oor die sondigheid van die verbondsvolk en dus die noodsaaklikheid van 'n korrektief (bv. Ps. 81; 89; 106-107). In Psalm 73 word geworstel met die probleem van die regverdige se lyding deur die goddeloses en word gekla dat God die regverdiges nie reg behandel nie. Tog kom die digter tot 'n korreksie op homself oor hierdie houding. Ook die wysheidsliteratuur word gedra deur 'n korrektiewe houding: 'n mens se lewe moet aan die Here verloor word om dit weer van Hom te ontvang ("Die vrees van die Here is die beginsel van die kennis/wysheid"; Spr. 1:7; vgl. Eichrodt, 1961:268-277). 
In Salomo se gebed by die inwyding van die tempel word die volk se sonde en God se reaksie daarop benadruk (1 Kon. 8:35-53; vgl. ook 2 Kon. 17: 13-20). Die profete se verkondiging was as't ware een lang oproep tot bekering (Dan. 9:6) en die ballingskap God se vernietigende straf op die verbondsvolk se diepliggende sondigheid, 'n korrektief om hulle tot bekering en gehoorsaamheid te bring. Dan sou God hulle 'n nuwe lewe gee as 'n volk met ' $n$ nuwe gesindheid in die beloofde land (Jer. 30-31; Eseg. 37).

\section{Die houding van die Ou Testament teenoor die ver- kondigers van die Woord}

'n Sentrale aspek van die verkondiging van die profete is die eis om bekering. Bekering impliseer 'n omkering met die hele hart, insluitende die gevoel, wil en verstand, 'n omkeer op die bestaande pad van optrede en denke (Stolz, 1971:865-866; Fabry, 1984:427-438). Die verbondsvolk was egter nie vatbaar vir hierdie ernstige eis om korreksie nie en is deur baie profete voorgepraat in hulle selftevredenheid; daarom sou die verloop van die geskiedenis gekenmerk word deur ontnugtering (Am. 5:18-20; Jes. 5:26-30; 10:5-6; ens.; Preuss, 1991:156). Die verbondsvolk en die vals profete het in valse gerustheid verkeer oor die Woord se eis om verbondsgehoorsaamheid en het self geen behoefte gevoel aan bekering nie (Jes. 1:10-17; Jer. 7:1-15). Die vals profete het slegs vir die mense gepreek, maar nie teen hulle nie (Miga 3:5-8; Preuss, 1992:90, 92) - die prediking van die vals profete was dus nie 'n korrektief nie.

Die geskiedenis van die mensdom het begin met ontnugtering weens hulle houding teenoor die Woord of gebod van God (Gen. 2-3); ook die einde van die geskiedenis sal deur ontnugtering gekenmerk wees (Matt. 25:3146; Luk. 13:25-27). Deur die ontnugterende gebeurtenis van die val van Jerusalem, die stad van God en die wegvoer van die verbondsvolk in ballingskap is die oppervlakkige heilsprofesie uitgewys as vals profesie wat Israel in valse gerustheid oor hulle verbondsposisie laat kom het. Juis die profete wie se verkondiging onpopulêr was en wat selfs daaroor vervolg is, is as verkondigers van die ware Woord van God uitgewys (vgl. Vriezen, 1966:25; Kaiser, 1993:219).

Die profete het nie slegs opgetree as voortdurende korrektief op die verbondsvolk en op die optrede van die koning nie (Helberg, 1980:117), maar hulle roeping en opdrag is ook gekenmerk deur 'n groot spanning tussen wat hulleself wou doen en sê en wat God hulle beveel het om te gaan verkondig. (Reeds die manier waarop God Homself met die naam Jahwe 
aan Moses bekend gemaak het, was 'n korrektief op die tipies menslike neiging om God volgens menslike begrip in te perk: vgl. Eks. 3: 13-15; Helberg, 1988:297; Von Rad, 1962:185.) Die Goddelike korrektief op die profete blyk ook uit die volgende: by Israel se versoek om 'n koning te hê, word Samuel, wat hierdie versoek as 'n verwerping van die Here beskou, tog beveel om vir hulle 'n koning aan te stel (I Sam. 8:22). Natan, wat Dawid se voorgenome tempelbou goedkeur, word beveel om Dawid van die plan te laat afsien (2 Sam. 7). Jesaja moet gaan preek sodat die volk nie verstaan en hulle bekeer en verlos word nie (Jes. 6:10). Esegiël kla gedurig oor die dwingende mag van die Here oor hom (Eseg. 1:3; 3:22; $33: 22 ; 37: 1)$. Jeremia bied tevergeefs weerstand teen die dwang wat hom opgelê is om die oordeel vir sy volk aan te kondig (Jer. 20). Hosea se ongelukkige huwelik met 'n prostituut moet selfs dien as vergestalting van God se liefde vir sy ontrou volk (Hos. 1-2, 11). In die geval van Jeremia en Hosea is daar ' $n$ duidelike tendens van die Woord om in die woordverkondiger gestalte te kry. Hierin word die menswording van die Woord, waarin veral die lydensaspek sterk na vore kom, afgeskadu (Joh. 1:1-14). Die boek Jona bevat 'n korrektief op die verbondsvolk en sy populêre profete oor hulle ongevoeligheid teenoor mense wat nie in God se verbondsgenade deel nie en bring God se universele erbarming sterk na vore (Jona $4: 11)$.

Die voorafgaande wys dat God se Woord, ook die mensgeworde Woord, nie bloot 'n geskenk aan die mensdom is nie, maar ook 'n korrektief op die mensdom, insluitende die woordverkondiger. Ook Psalm 1 verkondig hierdie feit (kyk hier onder).

\section{Die houding van die Ou Testament teenoor die leser}

Die hoorder of leser van die Ou Testament is nie bloot gesien as 'n neutrale toeskouer nie. Die Skrif is ' $n$ onderrigmiddel om as verbondsvolk van die Here te leef (Ps. 1, 19, 119). Daarom is die korrektiewe aard van die Ou Testament nie bloot bedoel om die hoorder/leser krities in te stel teenoor die mensdom, die volk Israel of indiwiduele mense nie, maar ook en veral as korrektief op die hoorder/leser self. Dit blyk uit Psalm 1. Hier word die ware bron waaruit die mens sy lewenskrag en voeding vind, aangedui as die Woord van God (תורדה), wat "dag en nag" deur die mens oordink word, dit wil sê waaraan hy geheel en al oorgegee en toegewy is. Hy gaan met die Woord om en ken die Woord; daarom leef hy 'n gekorrigeerde en korrigerende lewe; hy doen 'n besliste keuse teen die raad, weg 
en kring van die goddeloses. Sy lewe word geheel en al deur die Goddelike kennisbron bepaal. Vers 6 sê dat God die pad van die regverdige 'ken'. Die parallelle sinsnede ("die pad van die goddeloses lei tot ondergang") wys dat God se 'ken' hier meer as 'n intellektuele handeling is (vgl. ook Ps. 37:18). Daarom vertaal die 1983-vertaling "Die Here lei die regverdige op sy pad" (Kraus, 1972:9: "jd' hat hier die Bedeutung 'sich jmds. annehmen', 'jmd. mit inniger Anteilnahme begleiten', 'ihm nahe sein' ... 'für ihn sorgen': Ps 34, 16 ff.').

Hoewel die Psalm met die menslike handeling begin en daarop voortborduur, sê die laaste vers dat dit in werklikheid God is wat alle inisiatief het en alles bestier. Die woord 'ken' (רדע) word in Amos 3:2 gebruik om God se verkiesende optrede aan te dui (vgl. ook Rom. 8:29). Galasiërs 4:9 stel die Goddelike ken as inisiatief vir die menslike ken. Psalm 1 verkondig in wese dieselfde en gee daarmee ook 'n perspektief op die hele Psalmbundel waarvan dit die inleiding is (vgl. Kraus, 1972:10): God ken, lei ook die psalmdigters. Al skyn die Psalms die uiting van menslike gevoel te wees, is hulle nie bloot subjektiewe menslike gedagtes oor die openbaring van God nie, maar het die openbaring/Woord as bron en is in wese 'n korrigering van die menslike gedagtes of refleksie.

'n Verdere getuienis van die Ou-Testamentiese korrektiewe instelling teenoor die hoorder/leser is die sondebelydenis van psalmdigters (Ps. 6, 38, 51, $102,130,143$ ), asook hulle uitgesproke korrektief op hulleself (Ps. 42:6, 12; 43:5; veral 73). Die leser word voor die eis van selfkorreksie gestel by wyse van die vereenselwiging met die digter se situasie, of met die ware profeet wat homself moet verloën en nie volgens sy hart en verstand moet praat nie maar volgens God se openbaring. Verder word Israel, die dienaar van die Here, verwyt dat hulle hulle doof hou vir die Woord van God en nie na sy Woord wil luister nie (Jes. 42:19-20, 24).

Veral Johannes die Doper en Jesus het die korrektiewe aard van die $\mathrm{Ou}$ Testament benadruk. Hulle heel eerste verkondiging van die aanbreek van die koninkryk van God roep die lede van die verbondsvolk op tot bekering (Matt. 3:1; 4:17). Jesus kritiseer veral die Fariseërs en die Skrifgeleerdes, die mense wat met die uitleg van die Woord te doen het, dat hulle die Woord of Wet versaaklik en dit 'n voorwerp maak wat hulle in hulle eie greep hou (Matt. 15-17). Hulle snap nie die korrektiewe aard van die Woord ten opsigte van hulleself en ten opsigte van hulle benadering tot dié Woord nie. 


\section{Die houding van die Ou Testament teenoor homself}

Oor die algemeen het die Ou-Testamentiese boeke in hulle huidige vorm tot stand gekom deur 'n proses wat selfs voortgeduur het tot na die tyd van die skrywers op wie se naam hulle staan. Dit geld ook vir die profetiese boeke (vgl. byvoorbeeld Kaiser, 1993:231-262).

Daar was 'n aktualisering van tekste. Een voorbeeld hiervan is die verskille in die motivering van die sabbatsgebod (Eks. 20 en Deut. 5). 'n Ander voorbeeld is die verdrukking van Israel wat volgens Jeremia sewentig jaar sou duur, maar volgens Daniël 9 sewe maal sewentig jaar (Jer. 9:2, 24). Hierdie aktualisering wys dat die Bybelskrywers nie slegs eenheid nie, maar ook ' $n$ historiese verloop in die openbaring gesien het; anders gestel: openbaringsgeskiedenis. Openbaringsgeskiedenis impliseer eenheid, kontinuiteit en aktualisering.

Openbaring en geskiedenis is nie in botsing met mekaar nie; ook nie die Skrif en die natuur nie. Psalm 19 praat oor God se openbaring in die natuur sowel as in die Skrif, maar nie as twee onafhanklike openbarings nie. Om ware kennis van God te verkry, is die Skrif nodig (Calvyn, Institusie 1.6.2). Andersyds moet die Skrif gelees word in die lig van die omstandighede destyds sowel as vandag. Daar is soms by Israel se vermoë of tekortkominge aangesluit. Moses het byvoorbeeld egskeiding toegelaat weens die hardheid van die Israeliete se harte, sê Jesus (Matt. 19:8). Teenoor daardie soort gesindheid verkondig Hy 'n korreksie en verwys na die huwelik as 'n onverbreeklike verbintenis volgens die skepping, soos deur die $\mathrm{Ou}$ Testament geleer. Daarmee word die kontinuiteit en eenheid van die openbaring gehandhaaf.

Volgens Vriezen (1966:30-40) is die Ou Testament belas met allerlei oudOosterse voorstellings, selfs 'primitiewe' elemente: ou, verbygegane voorstellings en bepaalde antieke denkbeelde. Laasgenoemde word bloot uit estetiese oogpunt gebruik. 'n Mens sou volgens Vriezen dus kon praat van innerlike kritiek van die Ou Testament op homself, maar dit raak nie die wese van die $\mathrm{Ou}$ Testament se verkondiging nie. Die nasies het natuurgode en aanbid die bomenslike in allerlei vorms. Israel het egter 'n God wat die volk in die geskiedenis bevry het en as sy volk aangeneem het, die God van die wonder, die geskiedenis en die verbond. Hy is die nabye God en Hy hoor dié wat Hom aanroep. Hy het sy Woord gegee in sy wet (Deut. 4:7-8,19-40; Vriezen, 1966:60). 
Die Skrif self, of die openbaring van God self, word in die Ou Testament as volmaak beskou (Ps. 19:9; 119:96). Die tweërlei aspek van die Woord as volmaak, maar een wat tog aansluit by omstandighede, blyk ook uit die tekening van God as onveranderlik betroubaar maar tog nie strak onveranderlik nie (vgl. sy berou; 1 Sam. 15:10, 29 en sy reaksies op die mens se korruptheid; Gen. 6:5-7 en 8:21). Anders as in die magiese opvattings van die verbondsvolk se buumasies is God nie 'n gevangene van sy Woord nie. $\mathrm{Hy}$ is steeds in persoonlike beheer. Hoewel Genesis 8:21 oënskynlik 'n korreksie van God op sy eie vroeëre optrede is, getuig dit in werklikheid van sy grondelose genade en ontferming.

In ' $n$ sekere $\sin$ is daar in die Ou Testament self ' $n$ behoefte aan 'n grondliggende korrektief, byvoorbeeld in die verkondiging van die nuwe verbond in uitdruklike teenstelling met die oue (Jer. 31:31-34; Eseg. 36:26-27). Tog is die 'nuwe' duidelik nie te wyte aan 'n wesenlike verandering in God se optrede nie - inteendeel - Israel het die verbond verbreek, al was God getrou aan hulle (vs. 32). Die nuwe verbond sal nog wesenlik dieselfde wees: "Ek sal hulle God wees en hulle sal my volk wees". Die verskil tussen die ou verbond en die nuwe is dat God in sy onpeilbare en korrektiewe genade sy Woord op hulle harte sal skrywe en in hulle gedagte sal vaslê (vs. 33). Die grond is God se vergewing wat maak dat almal die Here sal ken (vs. 34).

\section{Jesus Christus en die Ou Testament}

Die voorafgaande laat ons verstaan waarom Jesus, die vervuller van die nuwe verbond, sê dat Hy nie gekom het om die wet en die profete ongeldig te maak nie, maar om hulle hulle volle betekenis te laat kry. Hy voeg daarby dat nie een letter of letterstrepie van die wet sal wegval voordat alles voleindig is nie (Matt. 5:17-18). Tog kom daar met sy koms iets so ingrypend anders dat 'n nuwe bedeling aanbreek, dié van die nuwe verbond of Nuwe Testament in vergelyking met dié een wat nou ou verbond of Ou Testament is (Heb. 8-9). Die aanbreek van die Nuwe Testament is in dié opsig korrektief dat dit saamhang met die oproep tot bekering, soos blyk uit Johannes die Doper en Jesus se eerste verkondiging van die koninkryk van God (Matt. 3:2; 4:17). Die Woord kry sy volle korrektiewe betekenis deur sy vervulling in Jesus Christus. Hy is die Woord wat een geword het met die mens, wat self mens geword het en selfs die vernietigende oordeel van God namens en vir die mensdom gedra het. So bring Hy verlossing uit 
loutere genade. Maar Hy stel ook die eis van die koninkryk van God: grondliggende korreksie, bekering, insluitende dié van denke.

In die koninkryk gaan dit nie bloot om Skrifgesag nie. Israel veins dat hulle die Woord van God graag nakom (Jes. 58:2) en die vals profete maak daarop aanspraak dat hulle die gesagvolle Woord van God verkondig (Jer. 28:11). Die Fariseërs en Skrifgeleerdes was meesters in voorspraak vir Skrifgesag, en tog het Jesus hulle skerp veroordeel. Ware Woordgesag raak die hart van die mens en dié sluit volgens die Ou Testament die hele mens in. Dit gaan in die Woord ook nie bloot om die koninkryk of die verbond as 'n saak of ding nie, of om verpligtinge soos offers en die nakoming van seremonies nie, maar veral om persoonlike verhoudinge daarom trek die openbaringsgeskienis saam in die menswording van die Woord. Verder vat Jesus die Ou Testament saam in die eis om die regte persoonlike verhouding tot God en die naaste. Konkreet beteken dit 'n lewe volgens die wil van God soos vervat in die Tien Gebooie. Tegelykertyd word 'n korreksie geimpliseer op die vraagstellers se wettiese benadering van die Woord (Matt. 22:34-36; vgl. Ridderbos, 1972:255-287; Grant, 1951:846-849).

Met die koms van Jesus Christus het daar inderdaad 'n nuwe bedeling aangebreek. Offers en seremoniële sake verdwyn en die fokus val op Christus wat skaduagtig daarin verkondig is (Heb. 1, 3, 7-10). In Hom vind daar 'n ware herinterpretasie plaas in die sin van aktualisering in die lig van die nuwe omstandighede wat deur sy koms aangebreek het. Hierdie herinterpretasie hang saam met die beloftekarakter van die Ou Testament. Die vervulling van beloftes put nie die beloftes heeltemal uit nie, maar gee inteendeel aanleiding tot verdere beloftes (vgl. Von Rad, 1965:372-374; 383384; sy herinterpretasie waarvolgens die historiese karakter van die $\mathrm{Ou}$ Testament in 'n groot mate verdwyn, moet egter afgewys word; vgl. Helberg, 1983:26-27). Die nuwe bedeling is nie wesenlik anders as die bedeling van die $\mathrm{Ou}$ Testament nie en is trouens deur die Ou Testament in vooruitsig gestel.

\section{Die betekenis van die korrektiewe aard van die $\mathrm{Ou}$ Testament vir teologiebeoefening}

Uit die voorafgaande bespreking blyk dat die Woord nie maar ' $n$ bron van kennis is om meer uit te vind oor God, die geskiedenis, dinge en mense nie, maar dat die Woord oproep tot antitese, veral antitese met die sondigheid in die leser self. Die leser moet hom bekeer. Dit vra grondliggende kor- 
reksie van homself in sy geheel, insluitende die manier waarop hy met die Skrif omgaan en dit verstaan. Jesus se woorde sal mense in die laaste dag veroordeel (Joh. 12:48; Heb. 4:12; vgl. ook Berkouwer, 1967:427). Ook teologiebeoefening word dus geraak. Die bekering moet een maal sowel as voortdurend gebeur. In hierdie sin eis die Skrif dus ge-reformeerde teologiebeoefening, en dit impliseer reformerende teologiebeoefening.

Die Skrif is die enigste en volmaakte ware norm en is die bril waarmee na alles gekyk moet word, ook na die natuur en die geskiedenis. Daarom mag die natuur, natuurlike verhoudinge of tradisie nie normgewende waarde hê vir teologiese besinning oor volkereverhoudinge, samestelling van kerke en kerkregering, seksuele verhoudinge, ensovoorts nie. Die korrektiewe aard van die Skrif se benadering tot hierdie verhoudinge moet ernstig geneem word.

In die lig van die voorafgaande kan na enkele tersaaklike benaderings van teologiebeoefening gekyk word. In hierdie verband kan slegs op enkele teoloë se beskouings gewys word, en dan ook net in hoofsaak. Jonker (1994) wys tereg op die rol van die gemeente in die teologiebeoefening en daarmee op die betekenis van die aktuele kontemporêre situasie en van die bestaansreg van ' $n$ verskeidenheid benaderings. Hiermee word nie 'n teologiebeoefening volgens menslike smaak gekondoneer nie, maar volgens menslike behoefte en volgens die korrektiewe Woord.

Barr (1983:4-14) oorwaardeer die inset en geloof van die gemeente. Hy meen dat die gedagte van ' $n$ kanon nie in die Ou Testament self gevind kan word nie en dat mondelinge verkondiging die belangrike was, nie 'n geskrif nie. Jesus het nie eens sy dissipels opdrag gegee om enigiets neer te skryf nie. Barr beweer daarom dat die Skrif sy ontstaan ontleen aan die geloof, nie die geloof aan die Skrif nie. Barr maak die fout om net in terme van die Skrif en die geloof te dink. Hy ignoreer die Goddelike openbaring. Die Skrif rus nie in menslike geloof nie, maar in die Goddelike openbaring wat reeds voor die (menslike) geloof daar was (vgl. ook Oosterhoff, 1967:2021: "wat de unieke geschiedenis interpreteert is niet Israëls geloof, maar het Woord van de Zich openbarende God"). Barr maak ook nie genoeg erns met die Skrifgedeeltes soos die volgende nie: "die Skrif(te) sê" (Matt. 21:42; 22:29; 26:54); "daar staan geskrywe" (Matt. 4:4, 6; 21:13; 26:31); "die hele Skrif is deur God geïnspireer" (2 Tim. 3:16). Hier word die Skrif as ' $n$ gesagvolle eenheid aangedui en dit juis in ' $n$ afwysende en korrektiewe houding teenoor menslike opvattings. Daarom is ook Barr se benadering van kumulatiewe openbaring onaanvaarbaar. Verder hou hy 
nie rekening met Jesus se uitspraak dat Hy gekom het om die Skrifte te vervul nie (Matt. 5:17). Childs $(1979: 40,58,59,74)$ sê tereg dat die kanon Goddelike openbaring is, nie 'n eksistensiële geskiedskrywing wat uitdrukking gee aan Israel se selfverstaan nie. Israel se selfverstaan het nooit 'n outonome plek gehad nie, maar is altyd geïnterpreteer in die lig van die gesag van die Skrif.

Die Ou Testament se aansluiting by mitologie is apologeties en korrektief. God is die absolute Skepper en Regeerder van alles. Die klem val op die onderhouding van die wil van God soos uitgedruk in sy Woord. In die verklaring van die Ou Testament is daar nie plek vir ontmitologisering nie (vgl. Helberg, 1983:23-24 oor Bultmann), want dit is reeds deur die Ou Testament self gedoen.

In die historisisme word die geskiedenis self gesien as 'n skeppende mag en daar word met 'n evoluerende gang in die verloop van sake gereken. Brueggemann (1992:141; vgl. ook Raitt, 1977:5) noem hierdie benadering tereg onhoudbaar. Eerder as die realiteit van ontwikkeling benadruk Brueggemann die realiteit van konflik in Jahwe se self-indentiteit volgens die Ou Testament. Brueggemann is egter te sosiologies in plaas van teosentries in sy benadering. Vandaar dat hy ook sterker klem lê op die skeppende krag van die praktyk van retoriek in Israel se sosiale diskoers as op die korrektiewe openbaringselement (Brueggemann, 1992:xvii).

Ons ondersoek wys dat die geskiedenis gekenmerk word deur korrektiewe, lewewekkende Goddelike optrede, eerder as evoluerende groei. In hierdie verband kan ook verwys word na die korrektiewe betekenis van die ballingskap. Die ballingskap het by Israel 'n drastiese hersiening van hulle lewe en benadering opgeroep (vgl. byvoorbeeld Klaagliedere). Ook hulle godsdienstige geskrifte is in die vuurproef van die harde werklikheid gewerp. Alleen dié wat die gees van ware verkondiging of profesie adem, kon die toets deurstaan (vgl. Vriezen, 1966:105-107). Dit was veral dié wat, anders as die mooiweersprofesie, bekering sterk beklemtoon het. Teenoor die historisisme wat vir die Ou Testament slegs 'n plek sien as deel van algemene godsdiensgeskiedenis, staan Vriezen (1966:157; vgl. ook Kaiser, 1993:21) tereg 'n teologiese benadering van die Ou Testament voor en erken daarmee die aanspraak van die Ou Testament om normatief te wees.

Die Ou Testament is nie maar die neerslag van menslike ervaring oor die openbaring en dus die Ou-Testamentiese gemeente se belydenis oor God 
nie, ook nie 'n skeefgetrekte en dus gekorrigeerde weergawe van die openbaring nie. Inteendeel, dit is die korrektiewe Woord van God. Menslike denke en ervaring speel nie 'n konstitutiewe rol in die Ou Testament nie. Laasgenoemde is 'n Goddelike gawe wat deur die mens aanvaar is (Van Wyk, 1990:39). Die Bybelskrywers speel 'n reseptiewe rol en nie 'n kreatiewe rol nie. Daarom is dit ten diepste nie maar net die mens wat die Woord uitlê nie, maar die Woord, in die hand van die Gees, wat die mens uitlê (Heyns, 1987:19-24). Volgens Kaufmann (1961:60) is hierdie aanvaarding intuïtief gedoen. Volgens Calvyn $(1.3 .1 ; 1.1 .2 ; 1.7 .4)$ het God die mens begiftig met kennis van Hom maar is die mens hoogmoedig; die Woord vind geen geloofwaardigheid in die hart van die mens voordat dit deur die innerlike getuienis van die Heilige Gees beseël word nie.

In die lig van die eenheid en kontinuiteit van die Ou Testament soos reeds bespreek is, staan Childs (1979) tereg 'n eenheidsbenadering van die $\mathrm{Ou}$ Testament voor en sien die Ou Testament as kanon - teenoor die fragmenterende histories-kritiese benadering. Die histories-kritiese metode kan volgens Rendtorff (1970:105-107) slegs sê wat God in die verlede gesê het maar nie wat hy vir die huidige leser sê nie.

Volgens Raitt (1977:225-227) word die kanongedagte weerspreek deur die feit dat die Ou Testament homself voortdurend herinterpreteer. Kanonisering impliseer volgens hom dat ons nou 'n post-kanoniese bestaan voer, met sub-kanoniese teologie, instellings, kultuur, gebeurtenisse en geskiedenis. Hierdie benadering van Raitt hou nie genoeg rekening met die genoegsaamheid van die openbaring wat in en deur Christus gegee is nie (Heb. 1:1-2; vgl. ook Bright, 1967:156-159; vgl. verder hier onder). Die openbaring in die Skrif kan wel in die teologiebeoefening stol wanneer daar nie erns gemaak word met die leiding van die Heilige Gees in die nuwe situasies nie. Dit is ook inderdaad ' $n$ vraag of ons teologiebeoefening nie soms by sommige historiese situasies van die Bybelse tyd of by sommige kerkhistoriese situasies vashaak nie. Tog moet daar met die volheid van die openbaring in Christus ems gemaak word en is daar nie ruimte vir 'nuwe' openbarings buite die openbaring wat in die Skrif gegee is nie. Ackroyd (1987:247) vergeet die uniekheid van Christus wanneer hy teen 'n geslote kanon pleit deur te verwys na die ingrypende veranderings waarvan die $\mathrm{Ou}$ Testament self praat (byvoorbeeld in die bekendmaking van die naam Jahwe, Eks. 6:3). Weliswaar kom die Ou Testament nie by 'n gearriveerde situasie uit nie maar is dit aktualiserend. Tog verwag die Ou Testament 'n unieke nuwe situasie met die nuwe verbond (Jer. 31:31-34; Eseg. 
36:26-27) en die openbaring trek vir die Ou Testament uiteindelik saam in 'n Persoon en die daaruit voortvloeiende persoonlike verhoudinge wat 'n blywende nuwe lig oor alles werp onder leiding van die Heilige Gees (Matt. 5; Joh. 14:16-17).

Alleen as die normatiewe én korrektiewe betekenis van die Ou Testament tot sy reg kom, kan teologiebeoefening vanuit 'n vaste grond werk én voortdurend reformerend wees. Deist $(1987: 8,13)$ pleit vir 'n radikale historiese benadering, anders stol die openbaring in die verlede. Hierteenoor moet gestel word dat dit nie hoef te gebeur nie, net so min as by die natuurwetenskap wat die werklikheid van die heelal bestudeer, in sommige gevalle werklikhede van baie lank gelede (vgl. Helberg, 1992:420 vir 'n bespreking van Deist). Die klem behoort gelê te word op die werklikheid van God wat in die geskiedenis werk, maar dit ook transendeer deur die werklikheid van sy openbaring.

\section{Samevatting}

Die Ou Testament staan basies korrigerend teenoor alle mense, lesers en teologiebeoefening en vereis dus bekering en voortdurende reformering volgens die Skrif, wat ruimte het vir aktualisering volgens tyd en omstandighede maar self die volmaakte en volledige norm is. Die Ou Testament wys na die nuwe bedeling wat gestalte kry in Jesus Christus in wie die gesagvolle geskrifte hulle vervulling vind. Sy kruislyding is God se kritiek en korrektief op die sondige mens en al sy inisiatiewe, ook die menslike inisiatief om God te probeer ken. Teologiebeoefening moet geskied in ootmoed, in die besef dat dit gebrekkige menslike nadenke is oor die Skrif as volmaakte Woord van God en daarom altyd weer daaraan getoets en daarvolgens gereformeer moet word. Soos die Skrif self, moet teologiebeoefening verder nie net veroordelend wees teenoor ander benaderings nie, maar korrektief, missionêr ingestel wees - om God deur almal te laat eer.

\section{Bibliografie}

ACKROYD, P.R. 1987. Studies in the Religious Tradition of the Old Testament. London : SCM.

BARR, J. 1983. Holy Scripture. Canon, Authority, Criticism. Oxford : Clarendon.

BERKOUWER, G.C. 1967. Dogmatische Studiën: De Heilige Schrift. II. Kampen : Kok.

BRIGHT, J. 1953. The Kingdom of God. New York : Abingdon.

BRIGHT, J. 1967. The Authority of the Old Testament. London : SCM. 
BRUEGGEMANN, W. 1990. First and Second Samuel. Louisville : John Knox. (Interpretation.)

BRUEGGEMANN, W. 1992. Old Testament Theology: Essays on Structure, Theme and Text. Minneapolis : Fortress.

CALVYN, J. 1984. Institusie van die Christelike godsdiens. Potchefstroom : CJBF.

CHILDS, B.S. 1979. Introduction to the Old Testament as Scripture. London : SCM.

DEIST, F.E. 1987. Relatiwisme en absolutisme: kan dit oorkom word? Oor 'Bybelse' en 'dogmatiese' teologie. (In Prinsloo, W.S. \& Vosloo, W. reds. Ou Testament teologie: gister, vandag en môre. Pretoria : NGKB. p. 117.)

EICHRODT, W. 1961/1967. Theology of the Old Testament. I/II. London : SCM.

FABRY, (sonder voorletters). 1984. leb. (In ThWAT. IV. Stuttgart : Kohlhammer. bl. 413-451.)

GRANT, F.C. 1951. The Gospel According to St. Mark. New York : Abingdon. (In Buttrick, G.A. ed. The Interpreter's Bible. VII. p. 627-917.)

HELBERG, J.L. 1980. Die Here regeer: Openbaringslyn deur die Ou Testament. Pretoria : NG Kerkboekhandel.

HELBERG, J.L. 1983. Verklaring en prediking van die Ou Testament. Potchefstroom : Potchefstroomse Teologiese Studies.

HELBERG, J.L. 1988. Die selfbekendstelling van God in Eksodus 3 en die betekenis daarvan vir vandag. Koers, 53(3):280-304.

HELBERG, J.L. 1992. Die betekenis van die Ou-Testamentiese teologie in die toekomstige Suid-Afrika. Old Testament Essays, 5(3):414-431.

HELBERG, J.L. 1994. Die boek Daniël. Kaapstad : NG Kerk-Uitgewers. (Skrifuitleg vir Bybelstudent en gemeente.)

HEYNS, J.A. 1987. Respons op F.E. Deist, Relatiwisme en absolutisme: kan dit oorkom word? Oor 'Bybelse' en 'dogmatiese' teologie. (In Prinsloo, W.S. \& Vosloo, W. reds. Ou Testament teologie: gister, vandag en môre. Pretoria : NG Kerkboekhandel. p. 18-28.)

JONKER, W.D. 1994. Reformed Theology and the Identity of a Christian Congregation. Ongepubliseerde voordrag gelewer by die International Theological Congress oor "The Vitality of Reformed Theology" te Noordwijkerhout, Nederland op 20-24 Junie 1994.

KAISER, O. 1993. Der Gott des Alten Testaments: Theologie des AT. 1: Grundlegung. Göttingen : Vandenhoeck.

KRAUS, H.-J. 1972. Psalmen. I. Neukirchen-Vluyn : Neukirchener Verlag. (Biblischer Kommentar.)

KAUFMANN, Y. 1961. The Religion of Israel: From Its Beginnings to the Babylonian Exile. London : George Allen \& Unwin. 
OOSTERHOFF, B.J. 1967. Feit of interpretatie? Rektorale rede: Theologische Hogeschool Apeldoom. Kampen : Kok.

PREUSS, H.D. 1991. Theologie des Alten Testaments. I. Stuttgart : Kohlhammer.

PREUSS, H.D. 1992. Theologie des Alten Testaments. II. Stuttgart : Kohlhammer.

RAITT, T.M. 1977. A Theology of Exile: Judgment/Deliverance in Jeremiah and Ezekiel. Philadelphia : Fortress.

RENDTORFF, 1970. Alttestamentliche Wissenschaft und Theologie. (In Siemers, H. \& Reuter, H.R. reds. Theologie als Wissenschaft in der Gesellschaft. Göttingen : Vandenhoeck. p. 102-117.)

RIDDERBOS, H.N. 1972. De komst van het koninkrijk. Kampen : Kok.

STOLZ, F. 1971. leh Herz. (In THAT. I. München : Kaiser. p. 861-867.)

VAN SELMS, A. 1967. Genesis. 1. Nijkerk : Callenbach. (De prediking van het Oude Testament.)

VAN WYK, J.H. 1990. Die Woord is waardevol: 'n dogmatiese besinning oor die reformatoriese Skrifbeskouing. Potchefstroom : Departement Sentrale Publikasies, PU vir CHO.

VON RAD, G. 1962. Old Testament Theology. I. Edinburgh : Oliver \& Boyd. VON RAD, G. 1965. Old Testament Theology. II. Edinburgh : Oliver \& Boyd.

VRIEZEN, TH.C. 1966. Hoofdlijnen der theologie van het Oude Testament. Wageningen : Veennian. 
